past two decades. Almost every teacher in the area probably has used it, at one time or another, as a text or as a source for his own lectures, so that The Balkans in Our Time is, along with Stavrianos, one of the best known modern books on the Balkans.

It is unfortunate, therefore, that Professor Wolff did not actually revise this edition, since the original weaknesses of the book remain, and the passage of time inevitably has added others. The first third of the book, which is based in some places on sources that are no longer adequate, is a tour de force of compression, but this makes it sketchy for the student new to the area. The final quarter of the book goes to the opposite extreme, especially from the vantage point of twenty years, by jamming too much partially digested economic and political data into the postwar Stalinist period. No one today would complain about an overemphasis on economic subjects, as the reviewer of the first edition did in this journal (Slavic Review, April 1957, pp. 214-16), but ephemeral data sorely need to be weeded out and an interpretive analysis grounded in economic or developmental theory added. In the political sphere, revisions, taking into account recent studies of Allied policies in Eastern Europe during the war and of the Cold War period, would make the book less dated.

One solution might have been to make the book explicitly a history of the Balkans from 1939 to Stalin's death, instead of keeping the theme of "our time." While some reorganization and considerable pruning would have been necessary, a more comprehensible unit would have resulted. Instead, Professor Wolff has simply added his afterword, which is a disappointment. Rather than ruminating on the significance of the events his book covers, he skims over two decades of development in his four countries, and closes with a series of questions that he suggests are provocative, but which are in fact didactic and unconvincing.

Wolff's nonrevision may be flawed, but the book remains one of the great achievements of Balkan studies in this country nonetheless. It still is a standard interpretation of the events it discusses, and an unusual number of its facts and interpretations remain unchallenged. If it is no longer quite the living text it was in the fifties, it is at least still alive, inching its way toward eventual status as a classic.

Gale Stokes

Rice University

TURSKA I DUBROVNIK U XVI VEKU. By Toma Popović. Belgrade: Srpska književna zadruga, 1973. 506 pp.

The sixteenth century marked the peak of the economic and cultural growth of Dubrovnik and of the military power and political influence of the Ottoman Empire. Mr. Popović traces the parallel course of the two developments, never forgetting to put them within the larger framework of Mediterranean and European history. He offers a chronological sequence of events in the relations between Dubrovnik and Turkey, centered mainly around the major wars in which Turkey was involved at the time and which very much affected Dubrovnik's precarious position on the edge of two worlds-the Ottoman in the East, the Christian in the West. The author, however, did not neglect the intervening periods of peace and their significance for Dubrovnik's relationship with the Ottomans. 
What emerges from this volume is a mosaic of events and ups and downs in Ottoman-Ragusan contacts, from which certain conclusions can be drawn: there was a constant strain in these relations, generated mostly at the lower, local level of the Ottoman administration, but sometimes present also in Ragusan dealings with the Porte itself. The impression is that Dubrovnik was continuously on the verge of being swallowed up by the Ottomans, but just as consistently managed to preserve its independence. This was due largely to the consummate skill of the Ragusan diplomats-their excellent intelligence services and their ability to foresee and to forestall adverse developments. The Ottomans, themselves, had a great interest in Ragusan survival. As Mr. Popović states: "On the edge of two worlds, Dubrovnik survived as a necessity for both, because it was the only one, among small states ... able to play the role of intermediary between them through a highly developed network of colonies in the Balkans and in the West, all the way to England, and through the strength of its merchant fleet" (p. 383).

The value of this book is in what it allows us to see of the functioning of the Ottoman state, especially of the relationship between the central and provincial administrations, and the changes they underwent as the century advanced and "the discrepancy between the new economic phenomena and the old political forms became increasingly obvious" (p. 386). In the end, Dubrovnik's fate was linked to that of the Ottoman state, because "by the strength of its economic relations Dubrovnik was vitally tied to Turkey" (p. 391). This is why the initial decay of the Ottoman Empire in the closing decades of the sixteenth century marked the beginning of Dubrovnik's troubles too.

The book has some minor flaws: the text is at times less than clear because of obvious restructuring and a too sparing use of dates, some themes are left unfinished, and a brief dictionary of Turkic idions and a map would have been helpful. Nevertheless, this is a volume well balanced in its judgments. Based on a vast amount of source material from the archives of Dubrovnik, Venice, and so forth, and on many Ottoman and other texts, it is a major contribution to our knowledge of the Balkans, as well as of the Ottoman Empire and the Eastern Mediterranean, at a crucial time in their history.

$$
\begin{array}{r}
\text { BARIŠA KREKIĆ } \\
\text { University of California, Los Angeles }
\end{array}
$$

\section{DALMACIJA 1870: RADOVI SA ZNANSTVENOG SKUPA U POVODU STOGODIŚNJICE POBJEDE NARODNE STRANKE NA IZBORIMA ZA SABOR DALMACIJE. Edited by Dinko Foretić. Zadar: Matica hrvatska, 1972. 298 pp. Paper.}

Over the past decade several useful studies have appeared on the national revival in Dalmatia in the nineteenth century (for example, Jakša Ravlić, ed., Hratski narodni preporod $u$ Dalmaciji $i$ Istri, Zagreb, 1969). The present volume is a Festschrift containing sixteen papers that were delivered at a symposium commemorating the centenary of the victory of the Nationalists in the 1870 elections for the Provincial Diet of Dalmatia. Although a mere 10 percent of the population had the vote under the existing Austrian electoral structure, the Nationalists' victory was a boost to the morale of the Habsburg Croats and other Slavs after 